\title{
Child Neglect and Internalizing Disorders: The Mediating Role of Emotion Regulation
}

\author{
Fatemeh Erfanifar ${ }^{* 1}$, Fariba Zarani², Omid Shokri², Shadi Kabiri Agh Ziarat ${ }^{3}$ \\ 1. M.A. in Child and Adolescent Clinical Psychology, Faculty of Psychology and Education, Shahid Beheshti University, Tehran, \\ Iran \\ 2. Assistance Professor, Department of Psychology, Faculty of Psychology and Education, Shahid Beheshti University, Tehran, \\ Iran \\ 3. Ph.D. Student of Health Psychology, Roodehen Branch, Islamic Azad University, Tehran, Iran
}

Received: March 10, 2018

Accepted: June 21, 2018

\begin{abstract}
Background and Purpose: Child neglect is associated with negative and long-term consequences in adolescence and adulthood such as internalizing disorders. Identifying the mechanism of the relationship between child neglect and internalizing disorders helps to identify the therapeutic interventions. The aim of this study was to examine the mediating effect of emotion regulation in the relationship between child neglect and internalizing disorders like mood disorders, anxiety disorders, and somatoform disorders.

Method: This study was correlational research. The sample of this study consisted of 200 high school female students in Tehran that were selected by multistage random cluster sampling. To collect data, self-reported child abuse, difficulties in emotion regulation scale and youth self-report scale, were used. Correlation and path analysis were used to analyze the data.

Results: The results showed that neglect of childhood indirectly and through emotional awareness can predict the symptoms of internalizing disorders in adolescent girls $(\mathrm{P}=0.001)$

Conclusion: In sum, results show that part of the common variance between the conceptual models of child neglect and internalizing disorders, is the result of the variability in emotional regulation.
\end{abstract}

Keywords: Child neglect, internalizing disorders, emotion regulation

Citation: Erfanifar F, Zarani F, Shokri O, Kabiri Agh Ziarat S. Child neglect and internalizing disorders: The mediating role of emotion regulation. Quarterly Journal of Child Mental Health. 2019; 6(1): 112-123.

\footnotetext{
*Corresponding author: Fatemeh Erfanifar, M.A. in Child and Adolescent Clinical Psychology, Faculty of Psychology and Education, Shahid Beheshti University, Tehran, Iran.

Email: Psy.fa93@gmail.com $\quad$ Tel: (+98) 9175967407
} 


\title{
غفلت و بع توجهى دوران كودكى و اختلانات دروننمود: نقش ميانجى تنظيم هيجان
}

\author{
فاطمه عرفانى فر"'، فريبا زرانى'، اميد شكرى '، شادى كبيرى آقزيارت \\ ا.كارشناسى ارشد روانشناسى بالينى كودك و نوجوان، دانشكده روانشناسى و علوم تربيتى، دانشكاه شهيد بهشتى، تهران، ايران

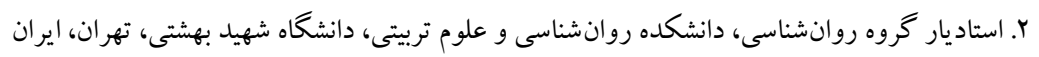

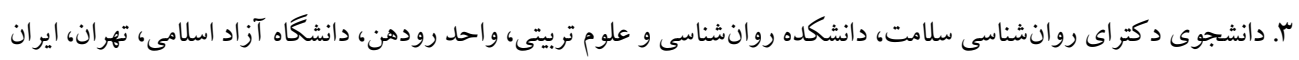

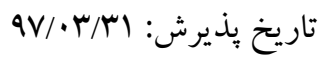

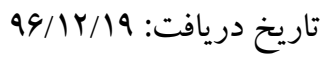

\section{جكيده}

زمينـه و هـــف: غفلـت دوران كودكى بـا ييـامـدهاى منفى زيادى در نوجوانى و جوانى ارتباط دارد. از جملة اين بيامدها مى توان به

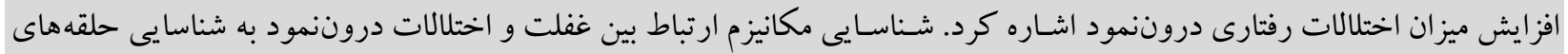

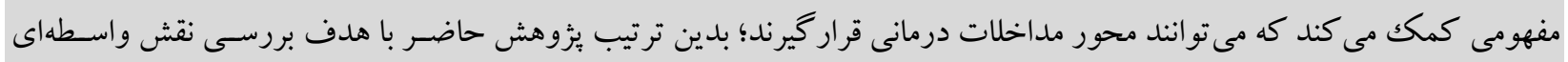

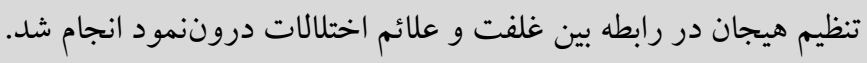

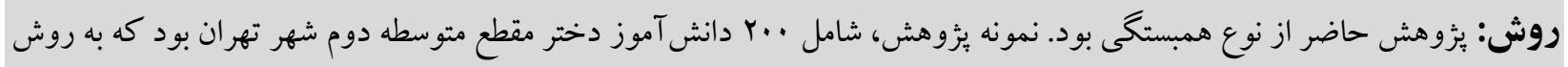

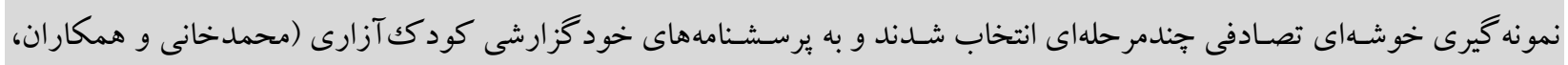

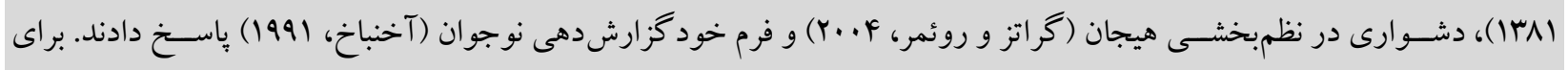
تحليل دادههاى بهدست آمده از روش همبستخى و تحليل مسير استفاده شد.

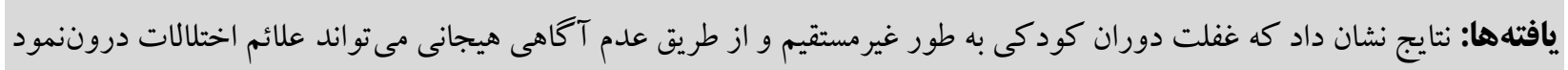

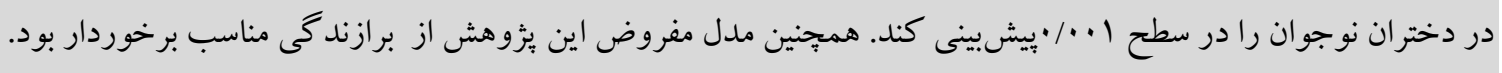
نتيجه كيرى: در مجموع، نتايج نشان مىدهد كه بخشى از واريانس مشتر كى بين حلقههاى مفهومى غفلت دوران كودكى و اختلالات درونتمود، نتيجة تغييريذيرى در تنظيم هيجان است. كليدوازهها: غفلت دوران كودكى، اختلالات دروننمود، تنظيم هيجان

*نويسنده مسئول: فاطمه عرفانى فر، كارشناسى ارشد روانشناسى بالينى كو دك و نوجوان، دانشكده روانشناسى و علوم ترييتى، دانشكاه شهيد بهشتى، تهران، ايران. 


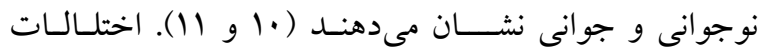

مقدمه

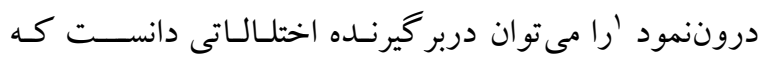

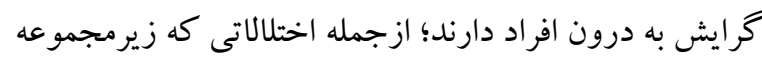

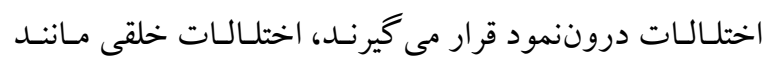
اختلال افسردگى اساسى و افسردهخويى است. ناتوانى كودكى در كســبـ وزن مورد انتظـار، بـىخو ابعى يـا يرخوابى روزانسه،

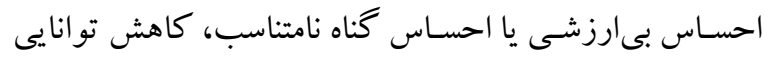

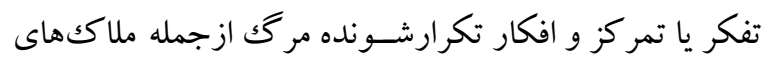
تشخيصى اختلال افسردگى اساسى در كود كى است. اختلال افسردهخويى نيز شـامل خلق افسرده و تحر يكك يذير در بيشتر اوقات روز و بيشتر روزها است كه البته در كود كان و نوجوانان

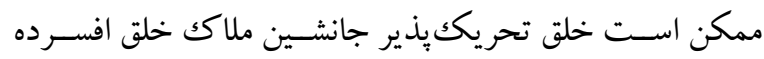

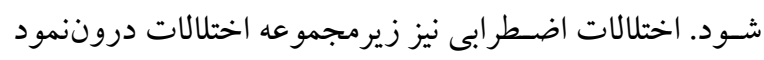

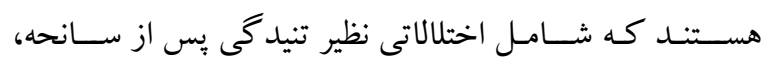

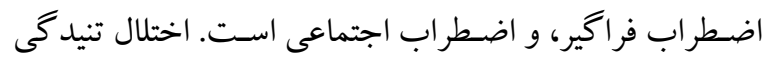
يس از سـانحه در كودكى و نوجوانى اختلالى اسـت كه ممكن است پِ از تجربه مستقيم سوءرفتار جسمى يا جنسى، خشونت

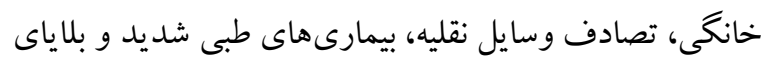

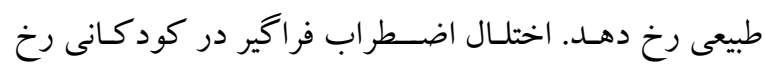

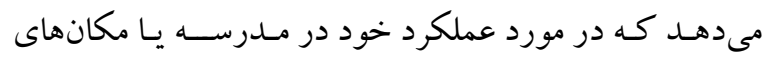

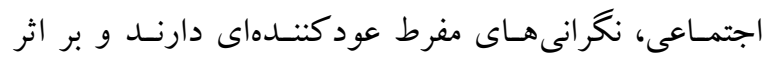

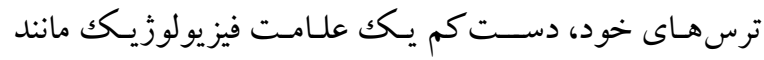

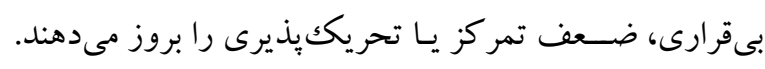

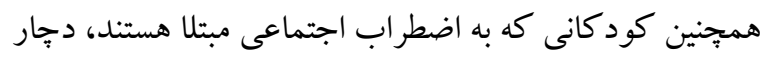
اضـطر اب شــديد و عود كنندهاى هسـتند كه در موقعيتهاى اجتماعى از توجه و تحقير توسط ديخر ان مىترسند و به همين

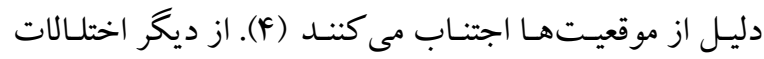

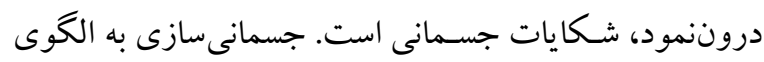

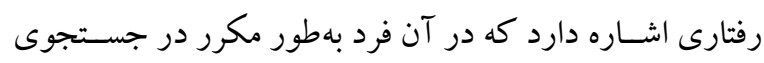

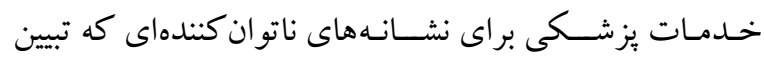

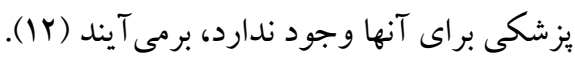

در دهـهـهـاى قبل تصــور مى شــــ در خانو ادههايى كه روابط

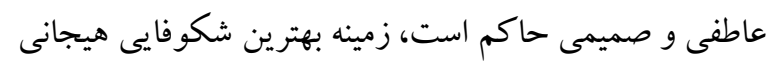

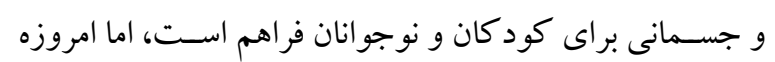

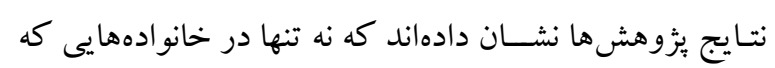
دجار تعارض هسـتند، بلكه در شــرايط خانو اد كىى كه ظاهراً

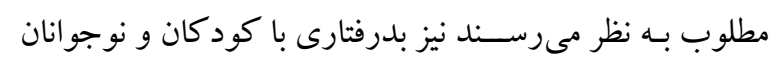

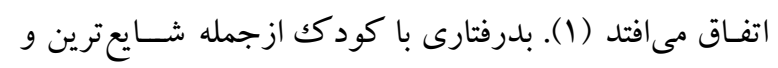

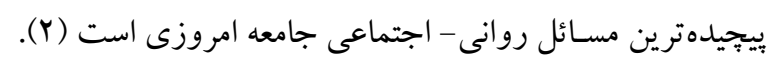
بـدرفتـارى دوران كـودكى، مجموعسهاى از انواع متفــاوت

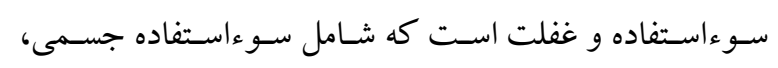

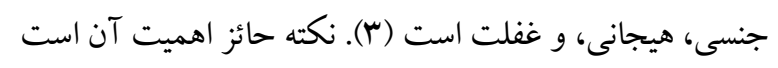
كه در ميان انواع مختلف بدرفتارى، غفلت ونس از شايع ترين اشكال

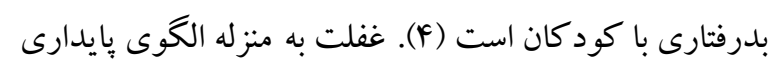

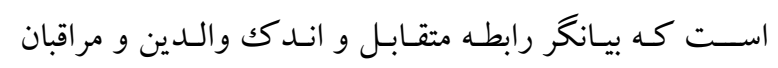

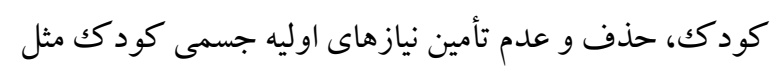

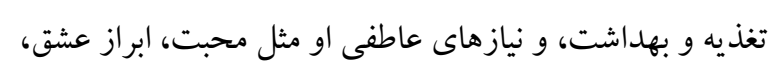

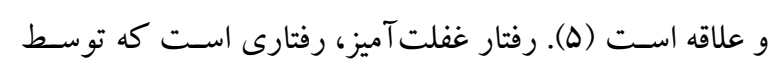

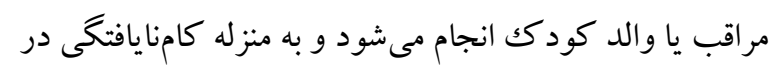

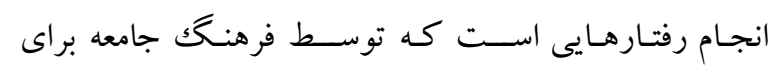

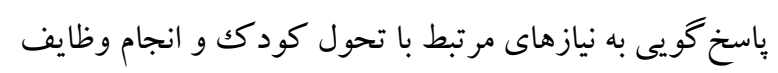

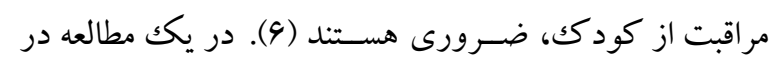

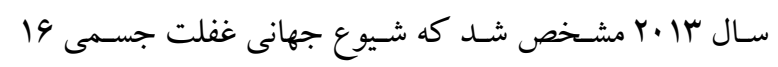

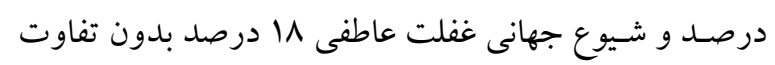

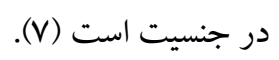
يزووهش هاى زيادى نشـان دادهاند كه كود كان آسيبديده

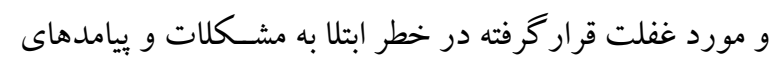

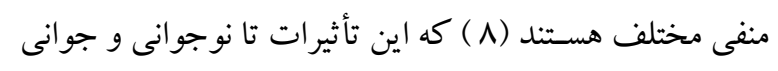

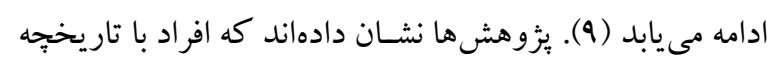
غفلت دوران كودكى نشانههاى اضطراب و افسردگى و به طور

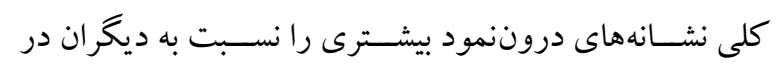

1. Internalizing disorders 
همجينين نظريـهــاى تنظيم هيجان، تنظيم هيجان انطباقى و

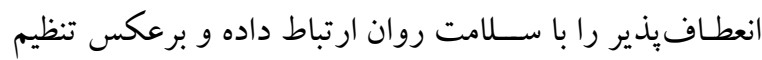
هيجـان غير انطبـاقى را بـه اختلـالـات روانى از جملـه اختلـالات دروننمود مربوط مىداند (19). دشوارى در نظمبخشى هيجان براى انواع اختلـالات دروننمود، نقش مركزى دارد و بين ابعاد مختلف تنظيم هيجـان با اختلالات درون نمود رابطه وجود دارد (Y.(Y). نارسايى در تنظيم هيجان از مشكلات بنيادين افراد مبتلا به

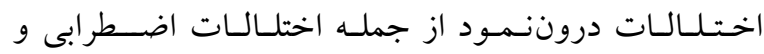

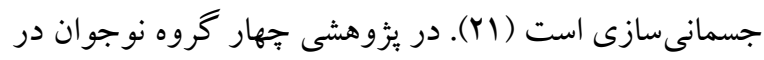
انواع راهبردهاى تنظيم هيجان با هم مقايسه شدند: نوجو انان با مشكلات دروننمود، نوجوانان با مشكلات برونتمود، نوجوانان

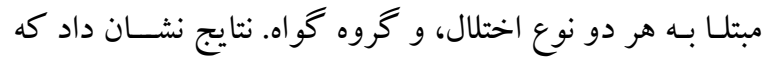

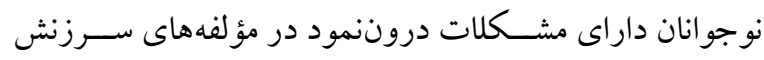

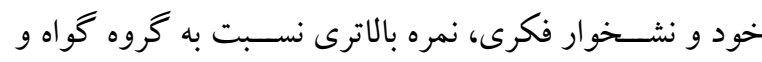
نوجو انانى كه مشكلات برون بمود داشته، دريافت كردند (YY). يُزوهش هاى بسـيارى نشـان دادهاند كه عدم آكاهى از هيجان بهلطور مثبتى با نشانهاى درون نمود مانند اضطر اب و افسردگى

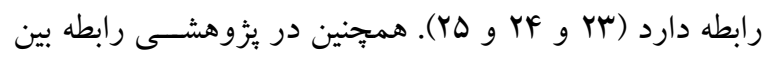
ناكويى طبعى كه از ابعاد تنظيم هيجان اسـت را با علايم اختلال

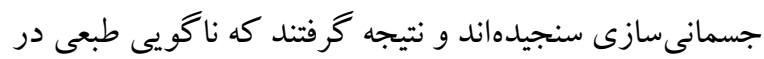
بروز علايم جسمانى سازى نقش مهمى دارد (Y) ).

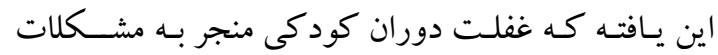

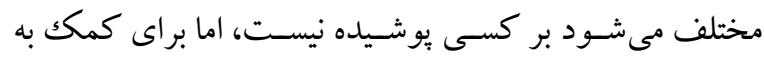

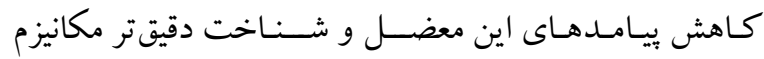
تأثير گذارى اين مسئله، بررسى عوامل ميانجى، ضرورى و مفيد به نظر مىرســ. شـواهد يُزوهشى نشـان دادهاند كه بين غفلت دوران كودكى و اختلالات دروننمود، غفلت دوران كودكى و راهبردهـاى تنظيم هيجـان، و از طرفى بين راهبردهـاى تنظيم هيجـان بـا اختلـالـات درونتمود، رابطـه معنــادار وجود دارد.

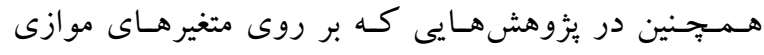
انجامشـدهاند، تنظيم هيجان را بهعنوان متغير واسـطهاى در نظر
از سـويى ديخر به نظر مىرسـد كه غفلت دوران كودكى' مى توانــد بر متغيرهـاى ديخرى از جملـه تنظيم هيجـان ' تـأثير

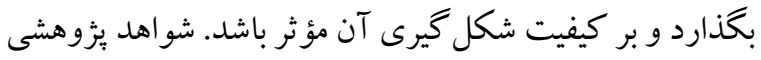
نيز رابطه بين غفلـت دوران كودكى و تنظيم هيجان را نشــان مىدهنـد. نظريـات تحولى، توانـا شــــن در تنظيم هيجانات را بهعنوان يكك مرحله تحولى برجسـته در كودكى، مدنظر قرار

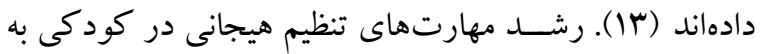
حضسور مؤثر و راهنمايى والدين نيازمند است اما ئزوهشهايى

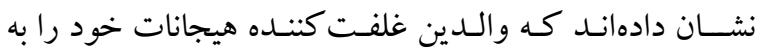
كود كانشــان، كمتر ابراز مى كنند و در گيرى كمترى در تبادل

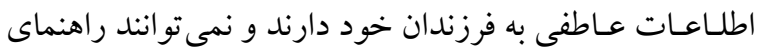
مؤثرى براى كود كك در جهت ياد گيرى تنظيم هيجانى باشــدـ

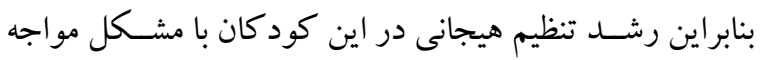
مىشـود (f) (1). در ئزوهشى نشان داده شد كه بين غفلت دوران كود كى و بدرفتارى عاطفى و اشـكال در شــاسـايى هيجانات، رابطه مثبت و معنادار وجود دارد (ها). علاوه بر اين در بثزوهش ديخرى مشخص شد كه اين كود كان نسبت به همسالان خود،

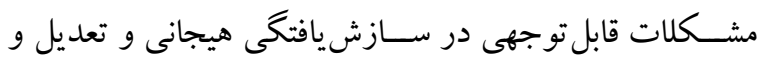
تنظيم هيجـان خود دارنـد (19). در مطالعهاى كه در رابطه بين

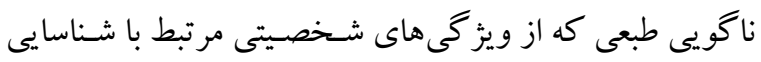
هيجات شـخصى است و غفلت دوران كودكى انجام گرفت، نشــان داده شـــ كه رابطه مثبت معنادارى بين ناكويى طبعى و غفلـت عـاطفى زودهنگـام دوران كودكى وجود دارد؛ در

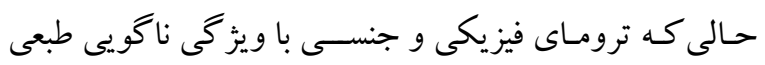

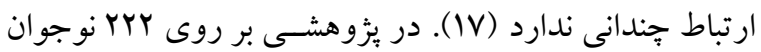
نشـان داده شــد كه غفلت دوران كودكى ســطح بايين تنظيم هيجـان را ييشبينى مى كنــ (r). تنظيم هيجـان را مى توان تغييراتى در فرايند هر سيستمى دانست كه باعث ظهور و بروز هيجانات در رفتار مى شــود. از زمانى كه هيجان فعال مى شــود اين تنظيم رخ مىدهـد و حتى قبل از بروز هيجان نيز اين تنظيم مشهود است (1) (1). 
هيجانى، نبود آكاهى هيجانى، و دسترسى محدود به راهبردهاى

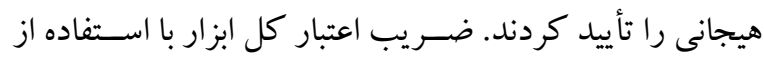
روشهاى همسانى درونى به/ • و براى هر كدام از 9زيرمقياس دشـوارى در نظمبخشى هيجانى، ضريب آلفاى كرونباخ بيشتر

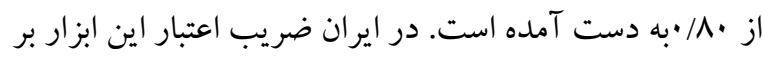
اساس آلفاى كرونباخ براى زيرمقياسها در يثزوهشى بين 91/. •

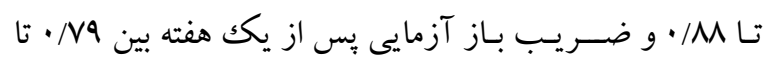

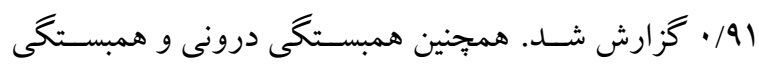

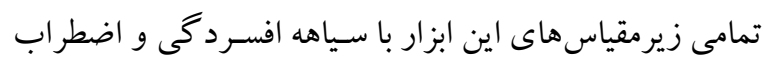

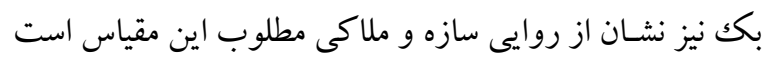

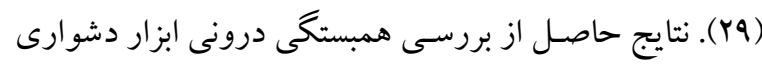
در نظمبخشى هيجانى نشان داد كه همبستخى هر گ گويه با نمره

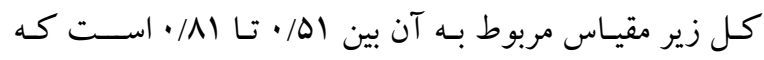

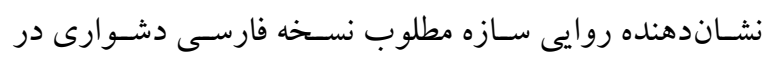
نظم بخشى هيجانى اسـت. در يزٔوهش حاضر، ضريب همسانى

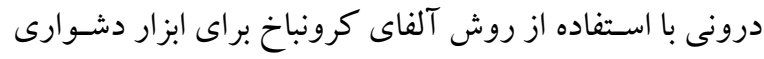

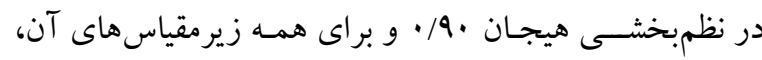
بالاى ه内/ · به دست آمد.

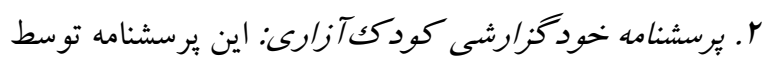

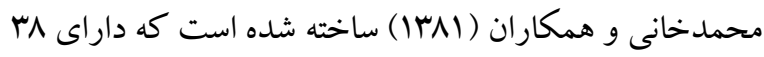

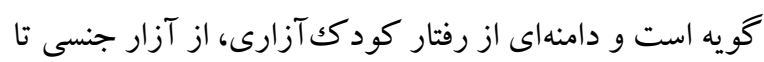
آزار عاطفى و جوّ منفى خانه، آزار جسـمى و بى توجهى نسبت

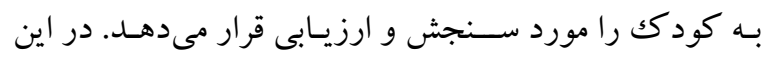
يرسشنامه لا سؤال به غفلت اختصاص دارد (·r). محمدخانى ضريب آلفاى كرونباخ براى ابزار خود گز ارشى كود كك آزارى

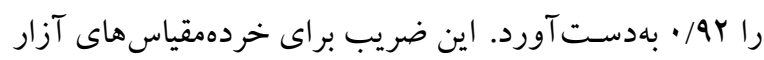

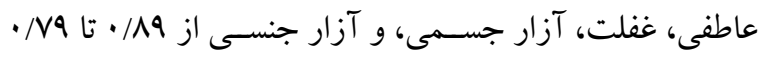
بوده و همجنين تمامى ضـرايب محاسبه شده در سطح ل ...

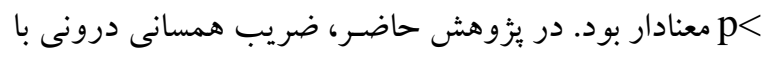

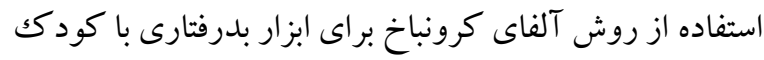

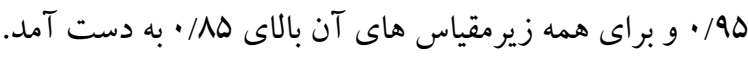

كرفتهاند (YV). بدين ترتيب ئزوهش حاضــر، تنظيم هيجان را بـهاعنوان متغير ميـانجى بين دو متغير غفلـت دوران كودكى و

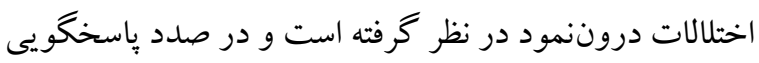

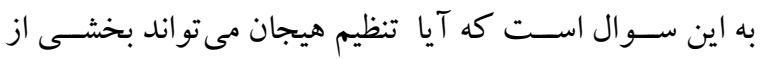

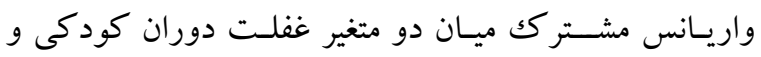
اختلالات دروننمود را تبيين كند؟

روش الف) طرح هزوهش و شـر كت كنند كان: يزوهش حاضـر از نوع بثزوهش هاى همبستخى است. جامعه بزّوهش حاضر شامل همه دانش آموزان دختر مقطع متوسطه دوم شهر تهر ان در سال تحصـيلى هQ روش نمونه گيرى خوشـهاى تصـادفى جندمر حلهاى از F منطقه

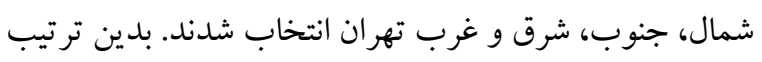

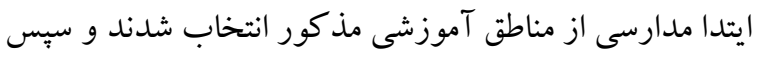

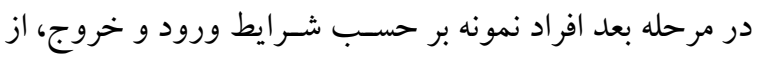
اين مدارس شـناسـايى و در مطالعه گنجانده شدند. معيار ورود

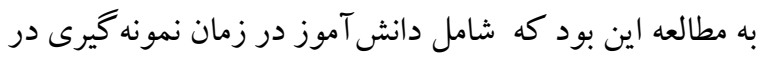
يكى از كلـاس هـاى مقطع متوســـه دوم شـــهـر تهر ان به طور

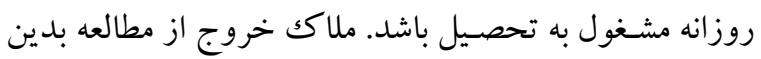

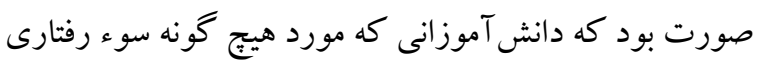

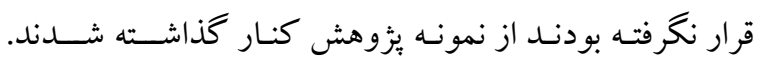

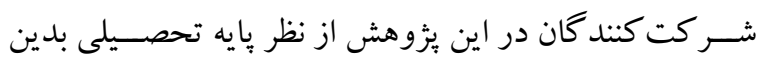
شـرح بودند: 91 نفر كلاس دهم، 94 نفر كلاس يازدهم، و 94

$$
\text { نفر كلاس دوازدهم. }
$$

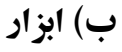
ا. يرسشــامه دشـوارى در نظمبخشسى هيجانى ': اين برسشنامه

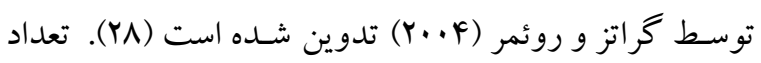

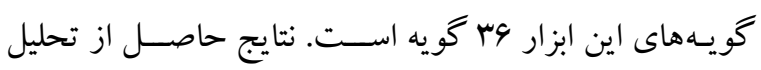

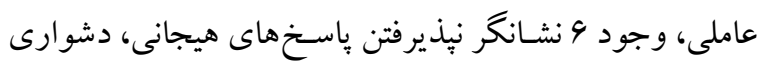

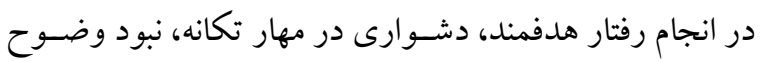


خردهمقيـاس هـا بـا نمره كلى بخش مربوطه و نقطههــاى برش بهدسـ آمده، نشـانگر اعتبار سازه مناسب اين ابزار است (آم).

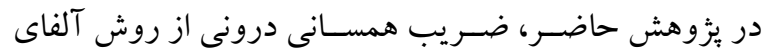

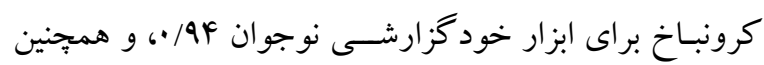

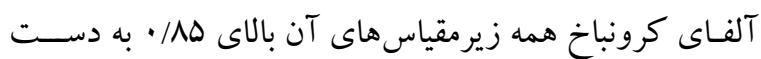

ج) روش اجرا: بعد از كسب مجوزهاى للازم علمى و اجرايى،

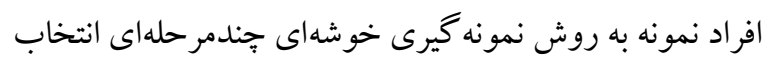

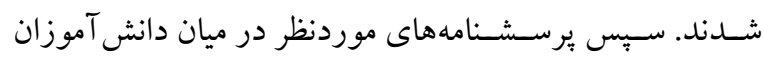
بهصورت گروهى اجرا شد و بهصورت همزمان به دانش آموزان در محيط كلاس داده شد. در اين مطالعات ملاحظات اخلاقى به به بهرب طور كامل رعايت شــــ. بدين ترتيب شـــركت داوطلبانه افراد

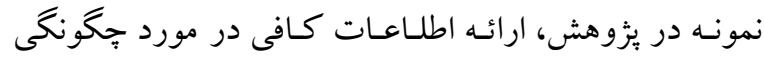

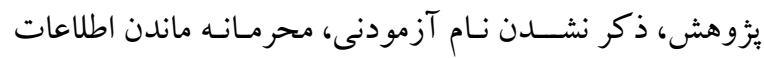

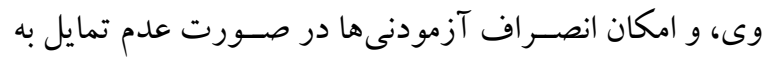
همكارى، در هر مرحله از ئزوهش رعايت شــه اسـت. يس از

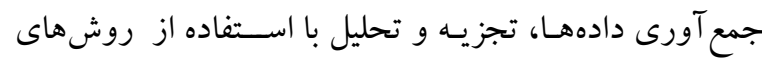
آمار توصيفى و استنباطى انجام شد.

\section{يافتهها} جدول ا شـاخص هاى توصيفى ميانگين و انحراف استاندارد، جولكى و كشيدگى رادر گروه نمونه نشان مى دهد. r. برسـشـنامه خود گزارشسى نوجوان: اين برسـشـنامه توسط آخنباخ' (1991) ساخته شده است و داراى دو بخش مهارتها ئرسي

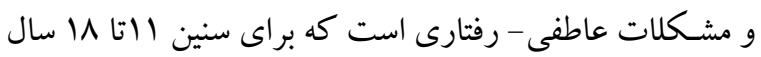

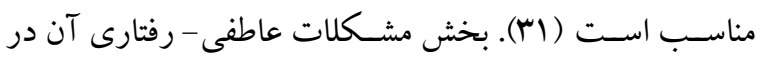

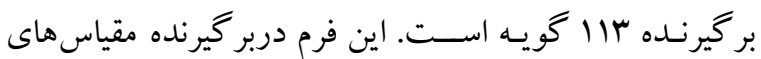
مبتنى بر تجربسه و مقيـاسهـاى مبتنى بر راهنمـاى آمـارى و

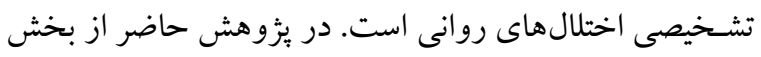
اختلـالـات درون تمود مقيـاس هـاى مبتنى بر راهنمـاى آمارى و و

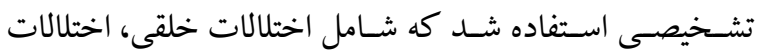
اضطر ابى، و اختلال جسـمانى سـازى اسـت. ضـر ايب همسانى درونى براى بيشــتر مقيـاسهـاى مبتنى بر تجربـه و مبتنى بر

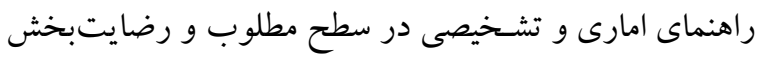
قرار دارد؛ بهطورى كه ضرايب همسانى درونى از طريق ضريب

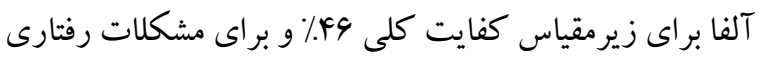

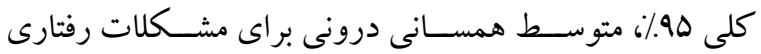
دروننمود و برون نمود ه9. ، و ضــريب آلفاى كرونباخ براى

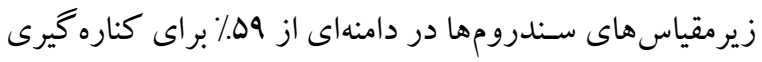

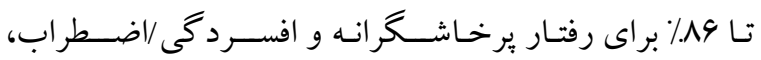
كزارش شده است. در ايران در يزوهشى ميزان آلفاى كرونباخ

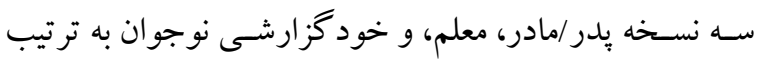

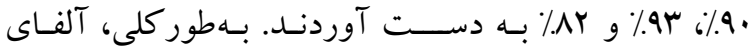
كرونباخ، همبســتخى ميان نســخهاى همتا، همبسـتخى ميان

جدول 1: جدول شاخصهاى توصيفى متغيرهاى يزووهش

\begin{tabular}{|c|c|c|c|c|}
\hline كشيدكى & جولكَى & انحر اف استاندارد & ميانكين & مقياسها \\
\hline$\cdot / \mathrm{NA}$ &.$/ 14$ & $\cdot \pi r$ & $r / 9 Y$ & غفلت و بى توجهى \\
\hline.$/ 94$ &.$/ \cdot 1$ & $\cdot / F r$ & $r / F q$ & نيذيرفتن ياسخ هيجانى \\
\hline .199 &.$/ 19$ & $F / A q$ & $\mid F / N r$ & دشوارى در رفتار هدفمند \\
\hline$\cdot / V^{F}$ & $\cdot / F r$ & $\Delta / 99$ & $10 / \cdot 0$ & دشوارى در مهار تكانه \\
\hline o & $\cdot|\wedge|$ & $r / \Delta)$ & $\Delta / Q 1$ & عدم وضوح هيجانى \\
\hline$\% r$ & $\cdot / \Delta \Lambda$ & $\Delta / M \Lambda$ & $|F / F|$ & عدم آكاهى هيجانى \\
\hline.$/ 49$ & .190 & $\cdot / 4 \Delta$ & $r / \Delta r$ & راهبردهاى محدود \\
\hline$\cdot \pi r$ & $\cdot / \Delta \Delta$ & . /v9 & $1 / N$ & اختلالات خلقى \\
\hline$\cdot / 4$. &.$/ \Delta$. & T/FF & $r / \Delta r$ & اختلالات اضطر بى \\
\hline$r / Y q$ & I/Ar & T/YG & $r / Y q$ & جسمانىسازى \\
\hline
\end{tabular}




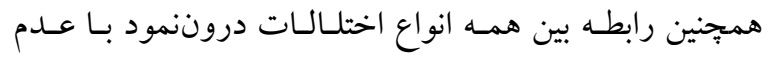

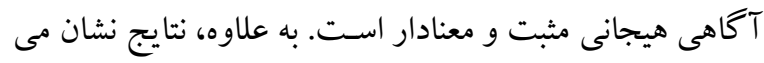
دهـد كـه بين غفلت و بى توجهى به كودك بانى با عدم آكاهى نيز رابطه مثبت و معنادار وجود دارد.
در جـدول r نتـايج مربوط بـه همبســتحى بين غفلـت و

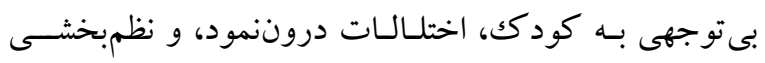
هيجان ارائه شده است. نتايج نشان مىدهد كه رابطه بين غفلت

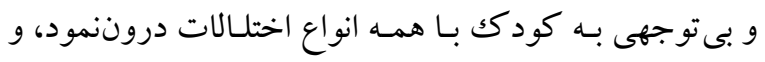

جدول ץ : ماتريس همبستغى بين غفلت كودكى، اختلالات دروننمود، و تنظيم هيجان

\begin{tabular}{|c|c|c|c|c|}
\hline جسمانى سازى & اختلالات اضطر ابى & اختلالات خلقى & غفلت كودكى & \\
\hline$\cdot / r \cdot$ 㫧㫧 & $\cdot / Y \backslash$ 拳米 & $\cdot /$ TV** & 1 & غفلت كودكى \\
\hline ./Yr*** & $\cdot / Y \mid * *$ & . /YF** & $\cdot / \Gamma q * *$ & آ آثاه \\
\hline
\end{tabular}

$* * \mathrm{P}<\cdot / \cdot 1 \quad * \mathrm{P}<\cdot / \cdot 0$

رعايت شـده اسـت. ضمناً در جهت مديريت دادههاى گمشده از روش بيشينه انتظار استفاده شد. در نهايت، به منظور آزمون

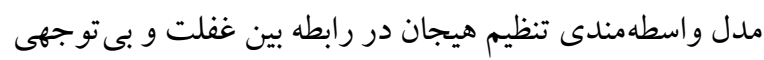

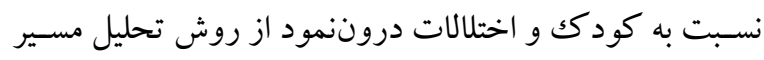

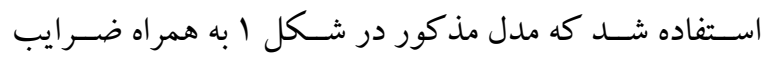

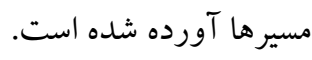

در مجموع، نتـايج حساصـل از روابط همبســــى ميـان متغيرهاى يُزوهش، شــرايط اوليه براى ورود متغيرها به مدل و

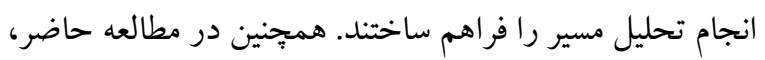

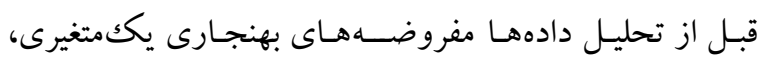
بهنجارى جندمتغيرى، و مقادير ڤيرت آزمون و تأييد شد. علاوه

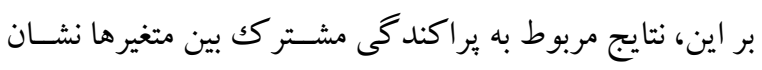

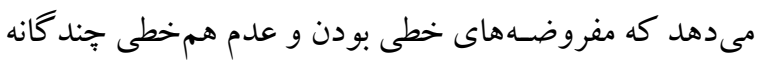

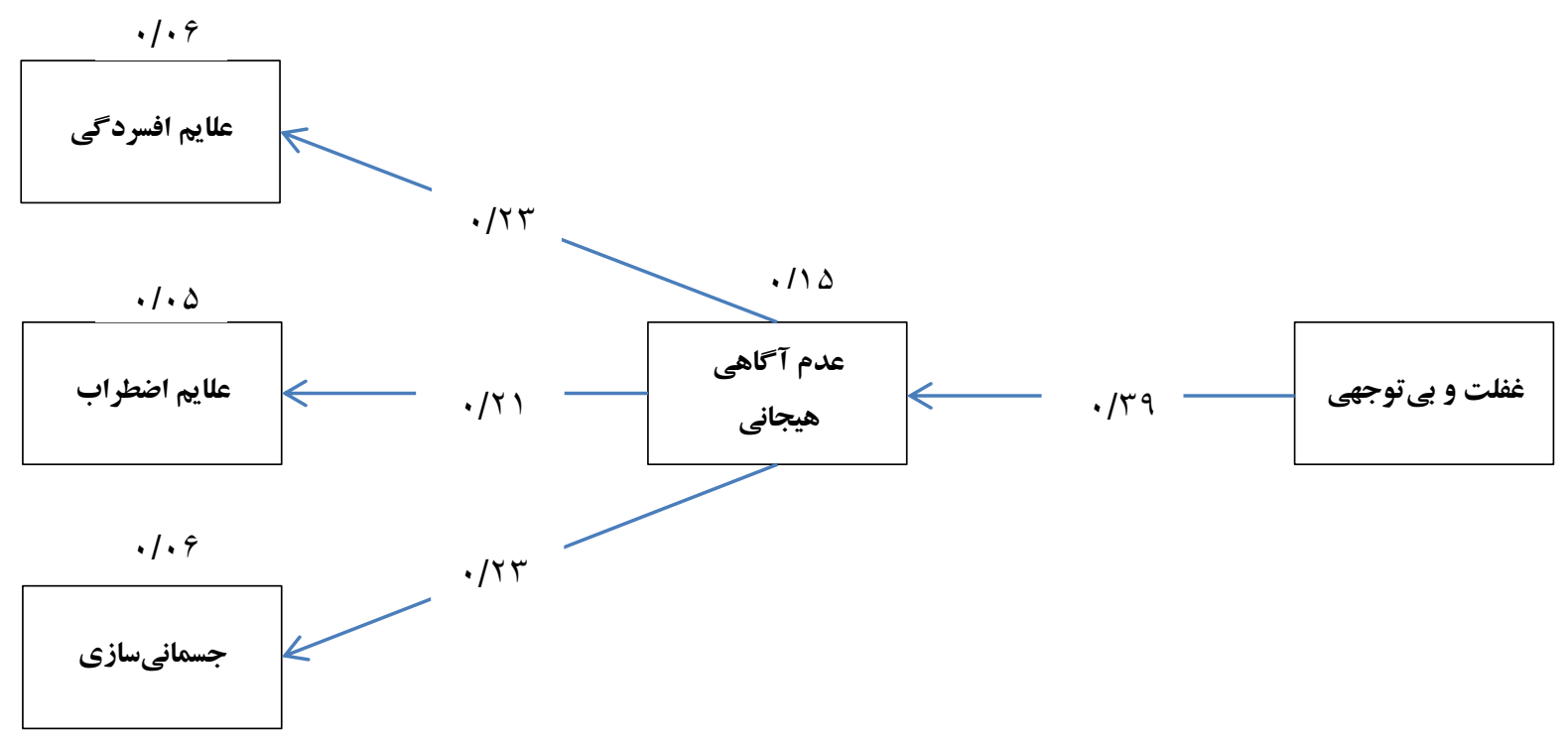

شكل 1: مدل مفروض واسطهمندى تنظيم هيجان در رابطه بين غفلت و بعتوجهى با كودك و اختلالات دروننمود

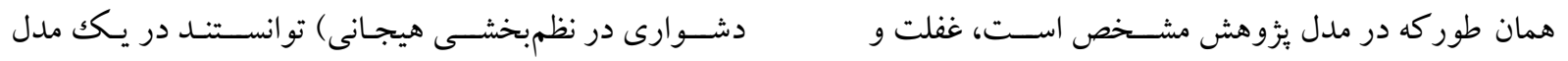

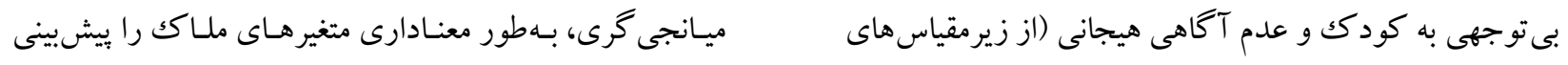


دادههـا نشـــان مىدهنــ كـه غفلـت و بى توجهى بـا كودكى بهصورت غيرمستقيم و از طريق عدم آكاهى هيجانى، بهطور

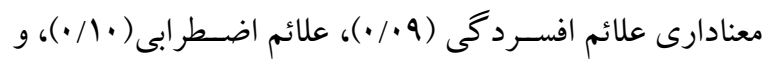

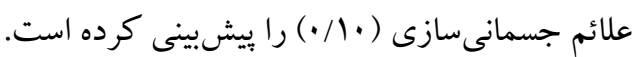

كنند. زيرمقياس هاى ديخر تنظيم هيجان به دليل نداشـتن نقش ميانجى در اين ميان، از مدل بثزوهش حذف شدند. همجِين ضريب استاندارد اثرات غيرمستقيم براى متغيرهاى مهن

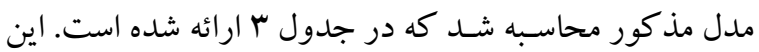

جدول "ז: اثرات مستقيم، غير مستقيم و واريانس تبيين شده

\begin{tabular}{|c|c|c|c|c|}
\hline واريانس تبين شده & كل & غير مستقيم & مستقيم & مسير \\
\hline .110 & $\cdot / 49$ & - & $\cdot / / 49$ & از غفلت به عدم آكًاهى هيجانى \\
\hline $.1 \cdot 9$ &.$/ .9$ & .1 .9 & $\cdot / \cdot$ & از غفلت به علايم افسردگى \\
\hline$\cdot / \cdot 0$ & $\cdot /$ &.$/$ & $\cdot / \cdot$ & از غفلت به علايم اضطراب \\
\hline .1 .9 & $\cdot /$ &.$八$ & $\cdot / \cdot$ & از غفلت به جسمانى سازى \\
\hline
\end{tabular}

\begin{tabular}{|c|c|c|c|c|}
\hline RMSEA & IFI & CFI & GFI & $\mathrm{X}^{2} / \mathrm{df}$ \\
\hline .1 .0 & $\cdot / 91$ &.$/ 99$ & ./9V & $1 / \Delta \Delta$ \\
\hline
\end{tabular}

\section{بحث و نتيجه كيرى}

يُووهش حاضـر با هدف بررسى نقش ميانجى تنظيم هيجان در رابطه بين غفلت و بى توجهى به كودك و اختلالات دروننمود

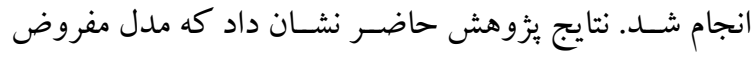
واسـطهمندى تنظيم هيجان در رابطة بين غفلت و بى توجهى به

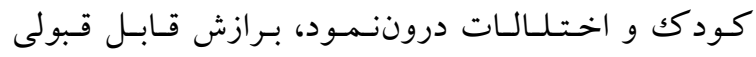
دارد (P=0.001)؛ به بيانديخر، نتايج بثزوهش حاضـر نشـان داد كـه مـتغير تنظيم هيجـان در بيونـــد دو متغير غفلـت و بى توجهى نسبت به كودك و اختلالات دروننمود در دختران نوجوان از نقش تفسيرى غيرقابل انكارى برخوردار است. اين

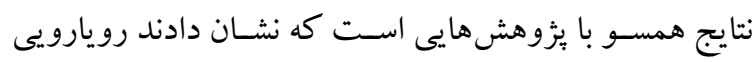

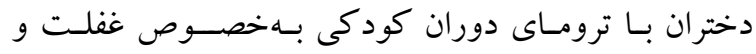
بى توجهى نسبت به كود كك با كاهش توانايى در تنظيم هيجان و افزايش ميزان اختلـالـات دروننمود در آنها، ارتباط معنادار

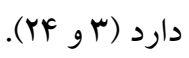

نتايج حاصسل از بررسـى مدل نشـان داد كه غفلت دوران كودكى بهطور غيرمسـتقيم و از طريق عدم آكاهى و دركك و

3. Fitness index

4. Root mean square error of approximation
در نهايت براى مدل ارائهشــده، شــاخصهاى برازندگى

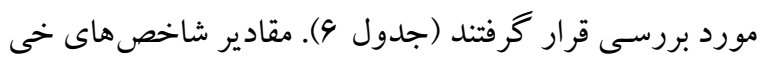

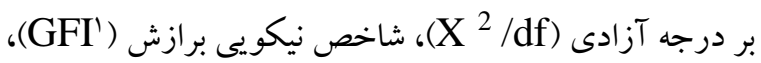
شـاخص برازندگى مقايسـهاى (CFI') و شـاخص برازند و شـاخص ريشــه خطـاى ميانگين مجذورات تقريب (IFI") (RMSEA $\left.{ }^{f}\right)$ دســت آمـد. در مجموع ، در اين مطالعه ارزش عددى مقادير

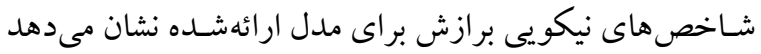
كـه مـدل مفروض بـا دادهــا برازش قابل قبولى دارد. همجينين براى بررسـى معنادارى اثرات غيرمسـتقيم مذكور، از آزمون

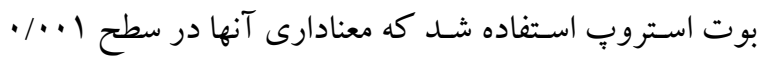

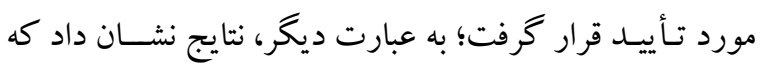
غفلت و بى توجهى نســبت به كود كك تو انســت از طريق عدم آكَاهى هيجـانى بـهور معنـادارى اختلـالـات دروننمود را بيشبينى كند.
1. Goodness of fit index

2. Comparative fit index 
احسـاسـات مىشـود. اشـخاص داراى ناكويى طبعى، اين اشارههاى بدنى را به صورت جسمى تفسير مى كنند؛ به همين

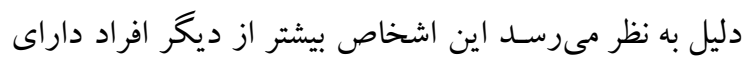
بيمارىهاى جسمى، تشخيص داده مىشوند (Y4). همانطور كه كفته شــد، افراد داراى ناكويى طبعى به اين دليل كه

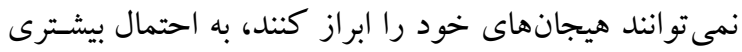

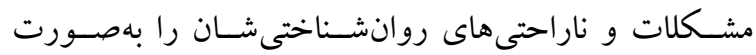

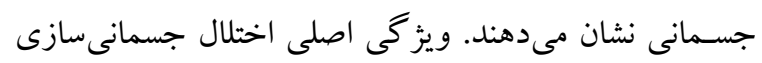

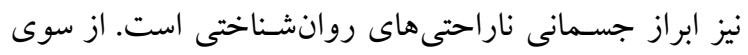

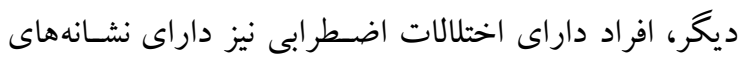
جسمانى زيادى هستـند كه ممكن اسـت به دليل مشككلات

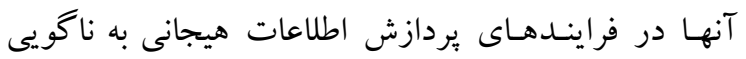

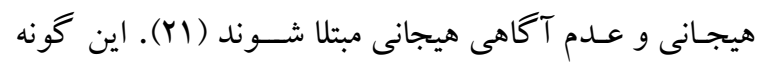
افر اد به دليل ناتو انى در بردازش شـناختى احسـاسـات خود و

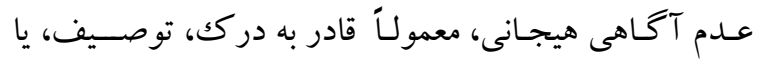

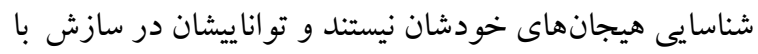

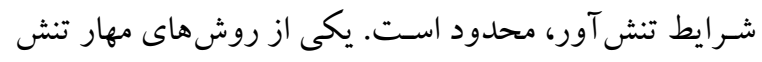
بـه خصــوص در مورد هيجانهاى منفى، بيان و تخليه هيجان ناشى از تنش است. درصورتى كه اين هيجانها تخليه نشوند و فرد نتوانند احساسات منفى خود را بهصورت كلامى بيان كند، جزء روانشناختى سيستمهاى ابراز هيجان و يريشانى روانى از

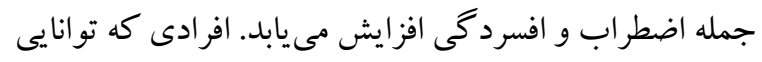

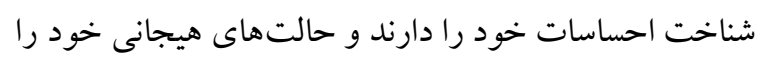

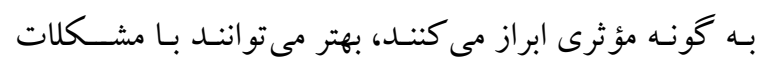

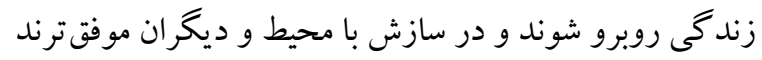

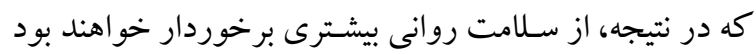

از محدوديت هاى يزوهش حاضــر مى توان بيان كرد كه

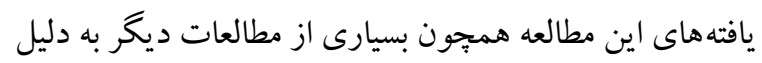

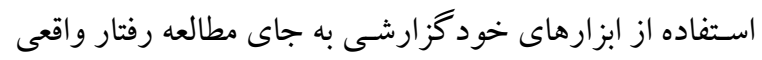
ممكن است مشاركت كنند كان را به استفاده از شيوههاى مبتنى
فهم هيجـانى بر علائم اختلـالـات دروننمود از قبيـل اختلالات

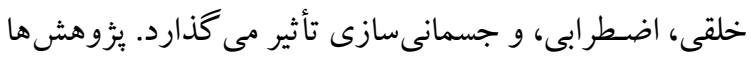

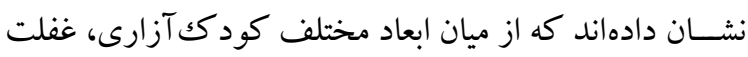
تنها بعدى اسـت كه با عدم آكاهى، شــاخت، و ابراز هيجان رابطه دارد (IV). همجنين يُزوهش هاى بسـيارى نشـان دادهاند كـه عـدم آكَاهى و ابراز هيجـان بـهـور مثبتى بـا نشــانههاى

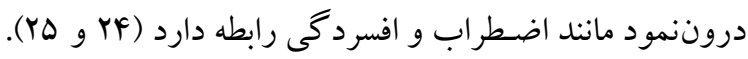
در تبيين يافته فوق مىتوان كفت كه غفلت عاطفى، شكستــ

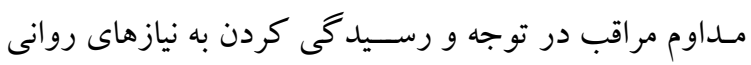
كودك اسـت. در جنين محيطى كودك ياد مى گيرد كه بيان

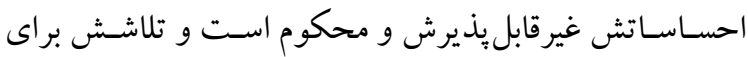

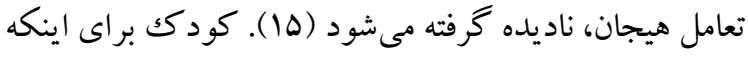

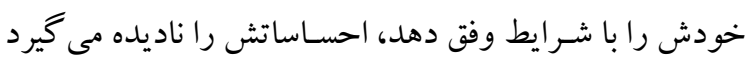
و يا بين خود و نيازهاى عاطفىاش، فاصسله ايجاد مى كند. اين

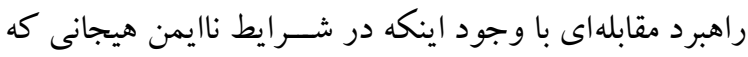

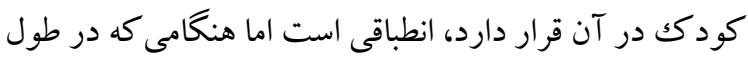
زمان از آن استفاده شود سبب ضعف آكاهى هيجانى در فرد

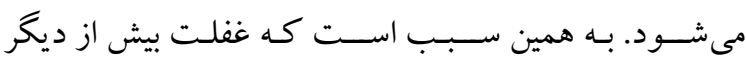

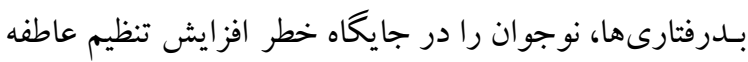

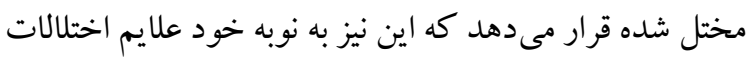
درون نمود را به وجود مى آورد (Y) (Y). در تفسـير اين يافتهها

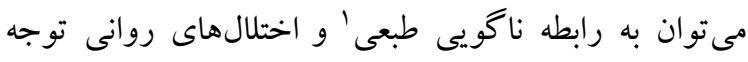

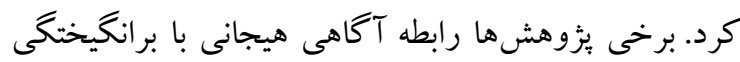

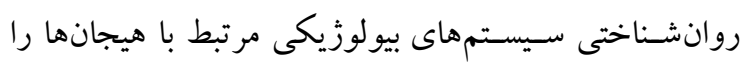

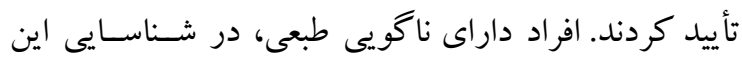
فرايند ناتوان هستـند و نداشـتن آكاهى از هيجانها، منجر به

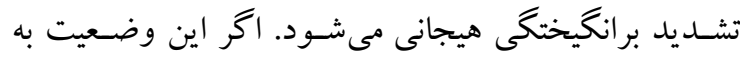

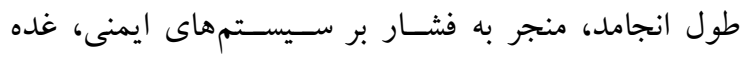

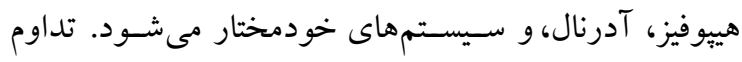

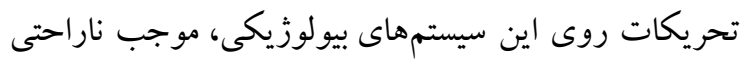

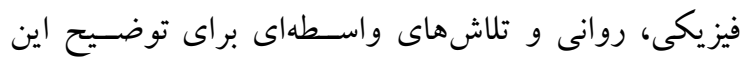


و الدين ارائه مىشود، بايد اهميت بازخوردها و رفتارهاى آنان، در شـكـل گيرى ديســـاه كودكـان و نوجوانـان در مورد احساسات خويش و نوع واكنش به هيجاناتشان، تصريح شود. در نتيجه، والدين بايد به مهارتهايى مجهز شــوند كه از يكك سو ظرفيت هيجانى و مديريت هيجانى فرزندانشان به حداكثر

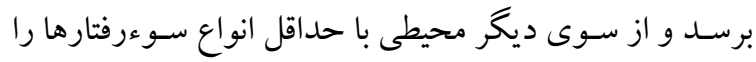

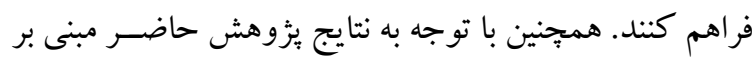

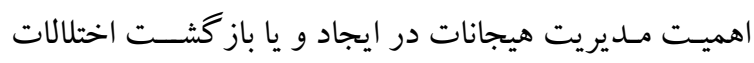
هيجانى و درون نمود، بيشـنهاد مى شـود كه در درمان مشكلات دختران قربـانى سـوء رفتـار از نوع غفلـت و بـتوجهى، بـهـ شــــاخـت هيجـان، آكَاهى هيجانى، و درك و فهم هيجان،

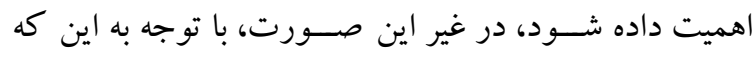
كنجينه هيجانى اين كود كان و نوجوانان قربانى، اندكك است،

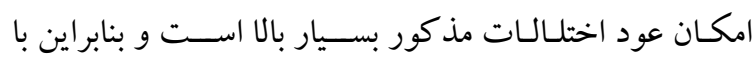

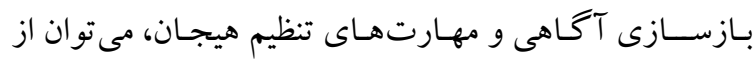
باز گشت اختلالات، جلو گيرى به عمل آورد.

تشـكر و قدردانى: اين يُزوهش بر گرفته از بايان نامه كارشـناسى

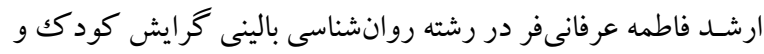

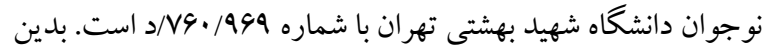

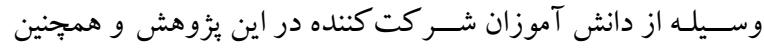

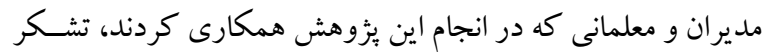

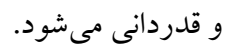

تضـاد منافع: اين بزوهش براى نويسند كان هيج گُنه تضاد منافعى

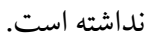

بر كســب تـأييد اجتماعى و اجتناب از بدنامى مربوط به عدم

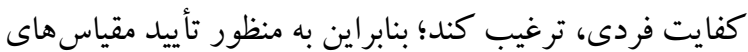

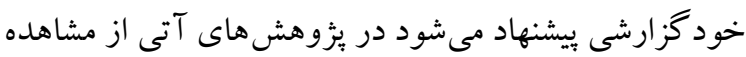
رفتارى و ديخر شـاخص هاى بالينى اسـتفاده شــود. از ديخر محدوديت هاى بزوهش حاضـر محدوديت در نمونه كيرى از

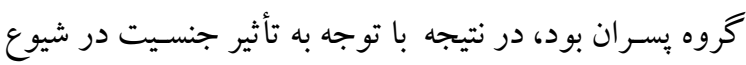

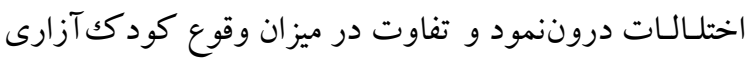

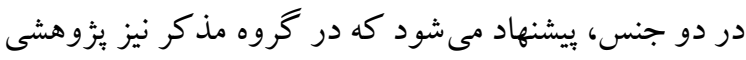

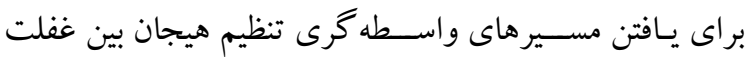

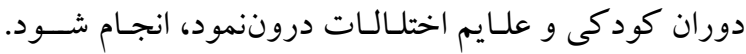
همجْنين براى مطـالعات آينده در جهت تكميل مدل حاضــر،

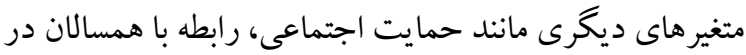

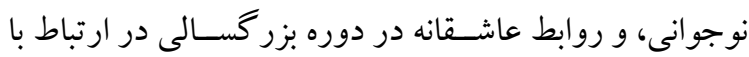
متغير هاى اين مطالعه، مورد بررسى قرار گيرند. بر اسـاس نتايج بزوهش حاضسر و با توجه به شـيوع بالاى اختلالات دروننمود از قبيل اضطراب و افسردگى در مراجعان نوجوان، به درمانگر ان توصسيه مى شــود كه با مشـاهده جنين

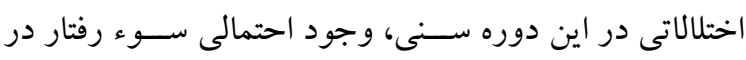
كذشــته و حال را مدنظر قرار داده و اثرات آن را را خنثى كنند.

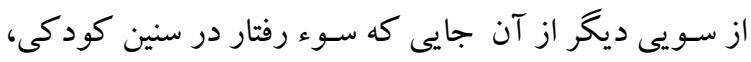
مديريت هيجانى آنها را در برابر حوادث آسيبزا دجار آسيب

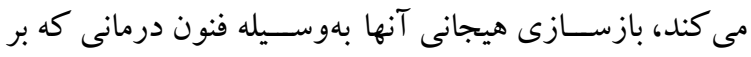

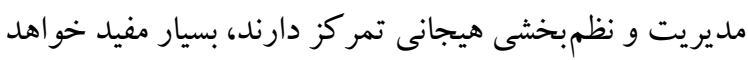

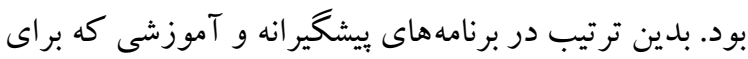




\section{References}

1. Mikaeili N, Zamanloo K. A study of the prevalence of child abuse and its prediction from parents' depression and anxiety, attachment styles and mental health of their adolescent boys. Psychology of Exceptional Individuals. 2012; 2(5): 145-166. [Persian]. [Link]

2. Briere J, Elliott DM. Prevalence and psychological sequelae of self-reported childhood physical and sexual abuse in a general population sample of men and women. Child Abuse Negl. 2003; 27(10): 12051222. [Link]

3. Mills P, Newman EF, Cossar J, Murray G. Emotional maltreatment and disordered eating in adolescents: Testing the mediating role of emotion regulation. Child Abuse Negl. 2015; 39: 156-166. [Link]

4. Sadock BJ, Sadock VA. Kaplan and Sadock's synopsis of psychiatry: behavioral sciences/clinical psychiatry. Tenth, North American edition. Philadelphia: LWW; 2007, pp: 2755-2756. [Link]

5. Albers EC, Reilly T, Rittner B. Children in foster care: possible factors affecting permanency planning. Child Adolesc Social Work J. 1993; 10(4): 329-341. [Link]

6. Straus MA, Kantor GK. Definition and measurement of neglectful behavior: some principles and guidelines. Child Abuse Negl. 2005; 29(1): 19-29. [Link]

7. Stoltenborgh M, Bakermans-Kranenburg MJ, van IJzendoorn MH. The neglect of child neglect: a metaanalytic review of the prevalence of neglect. Soc Psychiatry Psychiatr Epidemiol. 2013; 48(3): 345-355. [Link]

8. Eckenrode J, Laird M, Doris J. School performance and disciplinary problems among abused and neglected children. Dev Psychol. 1993; 29(1): 53-62. [Link]

9. Perez CM, Widom CS. Childhood victimization and long-term intellectual and academic outcomes. Child Abuse Negl. 1994; 18(8): 617-633. [Link]

10. Springer KW, Sheridan J, Kuo D, Carnes M. Long-term physical and mental health consequences of childhood physical abuse: results from a large population-based sample of men and women. Child Abuse Negl. 2007; 31(5): 517-530. [Link]

11. Cannon EA, Bonomi AE, Anderson ML, Rivara FP, Thompson RS. Adult health and relationship outcomes among women with abuse experiences during childhood. Violence Vict. 2010; 25(3): 291305. [Link]

12. Postilnik I, Eisman HD, Price R, Fogel J. An algorithm for defining somatization in children. J Can Acad Child Adolesc Psychiatry. 2006; 15(2): 64-74. [Link]

13. Southam-Gerow MA, Kendall PC. Emotion regulation and understanding: implications for child psychopathology and therapy. Clin Psychol Rev. 2002; 22(2): 189-222. [Link]

14. Bousha DM, Twentyman CT. Mother-child interactional style in abuse, neglect, and control groups: Naturalistic observations in the home. J Abnorm Psychol. 1984; 93(1): 106-114. [Link]

15. Goldsmith RE, Freyd JJ. Awareness for emotional abuse. Journal of Emotional Abuse. 2005; 5(1): 95123. [Link]

16. Pollak SD, Cicchetti D, Hornung K, Reed A. Recognizing emotion in faces: developmental effects of child abuse and neglect. Dev Psychol. 2000; 36(5): 679-688. [Link]

17. Aust S, Härtwig EA, Heuser I, Bajbouj M. The role of early emotional neglect in alexithymia. Psychol Trauma. 2013; 5(3): 225-232. [Link]

18. Campos JJ, Frankel CB, Camras L. On the nature of emotion regulation. Child Dev. 2004; 75(2): 377394. [Link]

19. Goodall K. Individual differences in the regulation of positive emotion: The role of attachment and self esteem. Pers Individ Dif. 2015; 74: 208-213. [Link]

20. Campbell-Sills L, Barlow DH. Incorporating emotion regulation into conceptualizations and treatments of anxiety and mood disorders. In: Gross JJ, editor. Handbook of emotion regulation. New York, NY, US: The Guilford Press; 2007, pp: 542-559. [Link]

21. Besharat M, Zahedi Tajrishi K, Noorbala A. Alexithymia and emotion regulation strategies in patients with somatization, anxiety disorders, and normal individuals: A comparative study. Contemporary 
Psychology, Biannual Journal of the Iranian Psychological Association. 2014; 8(2): 3-16. [Persian]. [Link]

22. Garnefski N, Kraaij V, van Etten M. Specificity of relations between adolescents' cognitive emotion regulation strategies and internalizing and externalizing psychopathology. J Adolesc. 2005; 28(5): 619631. [Link]

23. Poletti M, Frosini D, Pagni C, Lucetti C, Dotto PD, Ceravolo R, et al. Alexithymia is associated with depression in de novo Parkinson's disease. Psychother Psychosom. 2011; 80(4): 251-253. [Link]

24. Berthoz S, Consoli S, Perez-Diaz F, Jouvent R. Alexithymia and anxiety: compounded relationships? A psychometric study. Eur Psychiatry. 1999; 14(7): 372-378. [Link]

25. Motan I, Gençöz T. The relationship between the dimensions of alexithymia and the intensity of depression and anxiety. Turk Psikiyatri Derg. 2007; 18(4): 333-343. [Link]

26. Huber A, Suman AL, Biasi G, Carli G. Alexithymia in fibromyalgia syndrome: Associations with ongoing pain, experimental pain sensitivity and illness behavior. J Psychosom Res. 2009; 66(5): 425433. [Link]

27. Jennissen S, Holl J, Mai H, Wolff S, Barnow S. Emotion dysregulation mediates the relationship between child maltreatment and psychopathology: A structural equation model. Child Abuse Negl. 2016; 62: 51-62. [Link]

28. Gratz KL, Roemer L. Multidimensional assessment of emotion regulation and dysregulation: development, factor structure, and initial validation of the difficulties in emotion regulation scale. J Psychopathol Behav Assess. 2004; 26(1): 41-54. [Link]

29. Khanzadeh M, Saeediyan M, Hosseinchari M, Edrissi F. Factor structure and psychometric properties of difficulties in emotional regulation scale. Journal of Behavioral Sciences. 2012; 6(1): 87-96. [Persian]. [Link]

30. Mohammadkhani P, Mohammadi M, Nazari M, Salavati M, Razzaghi O. Development, validation and reliability of child abuse Self Report Scale (CASRS) in Iranian students. Medical Journal of the Islamic Republic of Iran (MJIRI). 2003; 17(1): 51-58. [Link]

31. Yazdkhasti F, Oreyzi H. Standardization of child, parent and teacher's forms of child behavior checklist in the city of Isfahan. Iranian Journal of Psychiatry and Clinical Psychology. 2011; 17(1): 60-70. [Persian]. [Link] 